\title{
Homofermentative lactic acid bacteria of a traditional cheese, Comlek peyniri from Cappadocia region
}

\author{
Cisem Bulut ${ }^{1}$, Hatice Gunes ${ }^{2}$, Burcu Okuklu², Sebnem Harsa ${ }^{1}$, Sevda Kilic ${ }^{3}$, Hatice Sevgi Coban ${ }^{2}$ \\ and Ali Fazil Yenidunya ${ }^{2 *}$ \\ ${ }^{1}$ Izmir Institute of Technology, Biotechnology Programme, 35430 Gulbahce, Urla, Izmir, Turkey
${ }^{2}$ Department of Biology, Science Faculty, Izmir Institute of Technology, 35430 Gulbahce, Urla, Izmir, Turkey
${ }^{3}$ Ege University, Faculty of Agriculture, Department of Dairy Technologies, Bornova, Izmir, Turkey
}

Received 12 December 2003 and accepted for publication 28 May 2004

\begin{abstract}
Comlek peyniri is a typical artisanal cheese in Central Anatolia. This type of cheese was made by using the indigenous lactic acid bacteria (LAB) flora of cow or ewes' milk. Majority of the samples were taken from fresh cheese because the aim was to isolate homofermentative LAB. Initially 661 microbial isolates were obtained from 17 cheese samples. Only 107 were found to be homofermentative LAB. These isolates were selected and identified by using both phenotypic and molecular methods. Phenotypic identification included curd formation from skim milk, catalase test, Gram staining and light microscopy, growth at different temperatures and salt concentrations, arginine hydrolysis, gas production from glucose, and carbohydrate fermentation. Molecular identification was based on the polymerase chain reaction-restriction fragment length polymorphism (PCR-RFLP) of the 16S rRNA gene-ITS (internally transcribed spacer) region. By combining the phenotypic and molecular identification results, isolates belonging to each of the following genera were determined at species or subspecies level: 54 Lactococcus lactis subsp. lactis, 21 Enterococcus faecium, 3 Ec. faecalis, 2 Ec. durans, 10 Ec. sp., 15 Lactobacillus paracasei subsp. paracasei, and $2 \mathrm{Lb}$. casei strains. Technological characterisation was also performed by culturing each of the strains in UHT skim milk, and by monitoring $\mathrm{pH}$ change and lactic acid production at certain time intervals through the $24 \mathrm{~h}$ incubation. Results of the technological characterisation indicated that $33 \%$ of the isolates (35 strains) were capable of lowering the $\mathrm{pH}$ of UHT milk below 5.3 after $6 \mathrm{~h}$ incubation at $30^{\circ} \mathrm{C}$. Thirty four of these strains were Lc. lactis subsp. lactis, and only one was an Ec. faecium strain.
\end{abstract}

Keywords: Identification, homofermentative lactic acid bacteria, 16S rRNA gene-ITS RFLP.

Traditional cheese fermentation is essentially based on the activity of indigenous LAB flora. Industrial production, on the other hand, requires defined starter cultures with desirable technological characteristics. Many of the commercial starter strains are homofermantative and they have been mostly selected and developed from Lactococcus species (Beresford et al. 2001). Starters initiate fermentation by producing lactic acid that results in curd formation. They also contribute to the maturation process by producing aromatic compounds via proteolytic activity. Furthermore, growth of certain pathogenic microorganisms can be inhibited or controlled by antimicrobial substances which are produced by the starter bacteria (Beresford et al. 2001).

*For correspondence; e-mail : afazilyenidunya@iyte.edu.tr
For the last two decades, Turkey has been experiencing an accelerating uncontrolled urbanisation. In parallel with this urbanisation, artisanal knowledge that propagates the traditional food making methodology through generations, disappears. This of course endangers the LAB microflora since little has been done to conserve the natural diversity of LAB.

Comlek peyniri is one type of traditional cheese and is very common in Central Anatolia. Although production recipes might change from one village to another, even among personal applications, the main steps of the process are as follows: clarification of raw milk, heating, cooling, the addition of rennet, incubation, pressing (whey expulsion), size reduction, salting, and finally ripening in earthen pots, which also serve as the packaging material. During the period of ripening, the pots are buried into volcanic 
ashes, tuff, locally called 'kisir', in the upside down position, in natural caves specific to the region. Maturation process lasts between 3 and 6 months and the consumption time coincides with the winter season.

In the present work, PCR-RFLP pattern analysis of $16 \mathrm{~S}$ rRNA gene-ITS clearly demonstrated that this method could differentiate strains of LAB at species level. Furthermore, the method also identified some diverged RFLP patterns within the strains of Lactococcus lactis subsp. lactis.

Technological characterisation of the isolated strains was carried out by measuring the acidifying activity and lactic acid production profiles (Cogan et al. 1997; Herreros et al. 2003).

The aim of this work was thus to characterize homofermentative $\mathrm{LAB}$ from a traditional Turkish cheese, Comlek peyniri, by using microbiological, molecular, and technological methods.

\section{Material and Methods}

\section{Origin of samples and reference strains}

In total 17 cheese samples were used for the isolation of LAB. Samples were obtained from the different stages of cheese making process. Reference strains were obtained from the Spanish Type Culture Collection (CECT) and Agricultural Research Service Culture collection (ARS, NRRL; Peoria, IL., USA): Lc. lactis subsp. lactis (CECT 4432), Lc. lactis subsp. lactis biovar. diacetylactis (CECT 4431), Enterococcus faecium (CECT 4102), Ec. faecalis (CECT 184), Ec. gallinarum (CECT 970), and Lactobacillus casei subsp. casei (NRRL B1922).

\section{Isolation and growth conditions}

Samples were analysed by the dilution pour plate method. Cheese samples $(10 \mathrm{~g}$ ) were homogenised in $90 \mathrm{ml}$ sterile, a quarter strength Ringers solution. Decimal dilutions of the homogenates were pour-plated on specific media for different groups of LAB : M17 agar medium (Terzaghi et al. 1975), $\mathrm{pH} 7 \cdot 15$, for lactococci; MRS agar medium, $\mathrm{pH} 6 \cdot 6$ (De Man et al. 1960) for lactobacilli; and for enterococci, Slanetz and Bartley medium, $\mathrm{pH} 7 \cdot 2$. All the pour-plates were incubated at $30^{\circ} \mathrm{C}$ for $3 \mathrm{~d}$. For the initial selection of homofermentative $\mathrm{LAB}$, randomly chosen colonies were cultured in reconstituted milk (RSM).

\section{Phenotypic identification}

Selection of isolates according to fermentative properties. Individual colonies were inoculated into $100 \mathrm{~g}$ RSM/l broths which were sterilised at $113{ }^{\circ} \mathrm{C}$ for $10 \mathrm{~min}$. They were incubated at $30^{\circ} \mathrm{C}$ for $24 \mathrm{~h}$, and changes in the appearance of RSM were monitored. When curd formation was achieved, the incubation was terminated. Another $24 \mathrm{~h}$ incubation was allowed for those cultures which could not coagulate skim milk during the first $24 \mathrm{~h}$. Thus, the isolates which were able to coagulate milk even after the $48 \mathrm{~h}$ incubation were also considered to be homofermentative LAB. Others were eliminated. Homofermentative isolates were then simple stained in order to observe cell shape and arrangements. Samples showing heterogeneous cell morphology were also eliminated. Consecutive subculturing was performed on the selected isolates. After Gram staining and catalase test, all Gram positive and catalase negative isolates were stored $-80{ }^{\circ} \mathrm{C}$ in MRS broth containing $20 \%$ glycerol.

Physiological and biochemical identification. For the phenotypic identification of cocci shaped isolates the following tests were performed: gas production from glucose, growth at different temperatures $\left(10,40\right.$ and $45^{\circ} \mathrm{C}$ ), and different $\mathrm{NaCl}$ concentrations (20, 40 and $65 \mathrm{~g} / \mathrm{l}$ ), arginine hydrolysis, and gas production from citrate. For species and subspecies level identification carbohydrate fermentation tests were performed in 96-well plates by using the following 14 substrates: $L(+)$-arabinose, $\mathrm{D}(+)$ galactose, lactose, maltose, $\mathrm{D}(+)$-mannitol, raffinose, sucrose, $\mathrm{D}(-)$-salicin, sorbitol, $\mathrm{D}(+)$-trehalose, $\mathrm{D}(+)$-xylose, glycerol, D(+)-mannose, and D(-)-ribose (Lopez-Diaz et al. 2000; De Urraza et al. 2000): cells from overnight cultures were pelleted by centrifugation at $9000 \mathrm{~g}$ for $10 \mathrm{~min}$ and were then washed and resuspended in MRS broth without glucose, containing bromocresol purple as the $\mathrm{pH}$ indicator. First, $40 \mu \mathrm{l}$ filter sterilised $(0 \cdot 22 \mu \mathrm{m}$ Millipore $)$ sugar solutions $(100 \mathrm{~g} / \mathrm{l})$ were pipetted into the each well, and $160 \mu \mathrm{l}$ cell suspension were then added. Two control experiments included in each of the plates were glucose fermentation (positive control), and cell suspension without any sugar (negative control). All the fermentation reactions were prepared in duplicates. After $24 \mathrm{~h}$ incubation at $30{ }^{\circ} \mathrm{C}$, the plates were read at $690 \mathrm{~nm}$ absorbance in an automated microtitre plate reader (Biotek Instruments Inc.). Sugar fermentation resulted in the change of the colour from purple to yellow, and turbidity was increased.

For the identification of rod shaped isolates gas production from glucose, growth at 15 and $45^{\circ} \mathrm{C}$, at $65 \mathrm{~g}$ $\mathrm{NaCl} / \mathrm{l}$ concentration, arginine hydrolysis, and 14 carbohydrate fermentation tests were performed.

\section{PCR-RFLP of $16 S$ rRNA gene-ITS region}

Genomic DNA was prepared by following the protocol of Cardinal et al. (1997) with some modifications. Cells from $10 \mathrm{ml}$ overnight cultures in MRS broth were harvested by centrifugation at $3300 \mathrm{~g}$ for $5 \mathrm{~min}$. The pelleted cells were suspended in $200 \mu \mathrm{l}$ lysis buffer (250 g sucrose/l and $30 \mathrm{mg}$ lysozyme/ml in $1 \times \mathrm{TE}, 10 \mathrm{~mm}$-Tris-HCl, $1 \mathrm{~mm}$-EDTA, $\mathrm{pH} 8$ ), and incubated at $37^{\circ} \mathrm{C}$ for $1 \mathrm{~h}$. After the lysis, $370 \mu \mathrm{l}$ proteinase $\mathrm{K}$ buffer $(1 \mathrm{mg}$ proteinase $\mathrm{K} / \mathrm{ml}$ and $12 \cdot 3 \mathrm{~g} \mathrm{SDS} / \mathrm{l}$ in $1 \times \mathrm{TE}, \mathrm{pH} 8$ ) were added. Samples were 
further incubated at $37{ }^{\circ} \mathrm{C}$ for $10 \mathrm{~min}$. Following deproteinization, $100 \mu \mathrm{l} 5 \mathrm{M}-\mathrm{NaCl}$ and $80 \mu \mathrm{l} \mathrm{CTAB} / \mathrm{NaCl}$ solutions (100 g cetyltrimethylammonium bromide/l and $0.7 \mathrm{M}-\mathrm{NaCl}$ ) were added, and the samples were then incubated at $65^{\circ} \mathrm{C}$ for $10 \mathrm{~min}$. Chloroform extraction was performed twice using one sample volume (Chloroform/ isoamyl alcohol: 24/1). DNA wool was obtained by the addition of one sample volume of isopropanol and washed in $500 \mu \mathrm{l}, 70 \%$ ethanol. DNA was then pelleted, dried and dissolved in $100 \mu \mathrm{l}$ RNase solution $(100 \mu \mathrm{g}$ RNase/ml in $1 \times \mathrm{TE})$. After incubation at $37^{\circ} \mathrm{C}$ for $1 \mathrm{~h}$ the volumes of the samples were adjusted to $400 \mu \mathrm{l}$ with $1 \times \mathrm{TE}$. DNA was solubilised by alternating heat shocks $\left(\right.$ at $80^{\circ} \mathrm{C}$ for $10 \mathrm{~min}$ and at $-20^{\circ} \mathrm{C}$ for $20 \mathrm{~min}$ ). After phenol/chloroform extraction, DNA was precipitated by adding $1 / 10$ sample volume of $5 \mathrm{M}-\mathrm{NaCl}$ and 2 volumes of $99 \%$ ethanol. Pellets were washed in $70 \%$ ethanol. Finally DNA was solubilised in $1 \times \mathrm{TE}$, and stored at $-20^{\circ} \mathrm{C}$.

Amplification of $16 \mathrm{~S}$ rRNA gene-ITS region was performed by using the following primers: Forward, 5'-AGAGTTTGATCCTGGCTCAG-3' (Mora et al. 1998); and reverse, 5'-CAAGGCATCCACCGT-3' (Jensen et al. 1993). The forward primer is complementary to the upstream of $16 \mathrm{~S}$ rRNA gene of Escherichia coli K12 strain (Accession number: AE000452, nucleotides from 1 to 20), and the reverse is complementary to the upstream sequences of 23S rRNA gene of Esch. coli 278710 (Accession number: AJ278710, nucleotides from 18 to 32). Each of the polymerase chain reactions (PCR) was performed in a $50 \mu \mathrm{l}$ reaction volume containing $50 \mathrm{ng}$ genomic DNA as the template, $0 \cdot 2 \mathrm{~mm}$-dNTPs, $1.5 \mathrm{~mm}-\mathrm{MgCl}_{2}, 10 \mathrm{pmol}$ each of the DNA primers in $1 \times \mathrm{PCR}$ buffer $(10 \mathrm{~mm}-\mathrm{Tris}-\mathrm{HCl}$, $50 \mathrm{~mm}-\mathrm{KCl}, 8 \mathrm{~g}$ Nonident P40/l, pH 8; MBI Fermentas, Lithuania), and 1.25 units Taq DNA polymerase (MBI Fermentas). Amplification conditions were as follows: an initial denaturation step of $5 \mathrm{~min}$ at $94{ }^{\circ} \mathrm{C}$; 40 amplification cycles, each consisting of 1 min denaturation at $94{ }^{\circ} \mathrm{C}, 1 \mathrm{~min}$ annealing at $42{ }^{\circ} \mathrm{C}$, and $1 \mathrm{~min}$ elongation at $72{ }^{\circ} \mathrm{C}$, steps. Reactions were terminated with a final extension step for $10 \mathrm{~min}$ at $72{ }^{\circ} \mathrm{C}$. PCR amplifications were performed in a Mini Cycler System (MJ Research INC., USA).

Two restriction endonucleases, Haell and Taql (MBI Fermentas), were used for the digestion of amplification products, differing in size from $1700 \mathrm{bp}$ to $2000 \mathrm{bp}$. One fourth of the amplification products, approximately $200 \mathrm{ng}$, was digested with 10 units of each of the enzymes overnight. Before and after the digestion, DNA was extracted twice with chloroform and precipitated with ethanol (Sambrook et al. 1989).

Half of the digestion products were resolved in 2.5\% agarose gel (Applichem, low EEO) by gel electrophoresis for $2.5 \mathrm{~h}$ at $60 \mathrm{~mA}$ in $1 \times \mathrm{TAE}$ ( $40 \mathrm{~mm}$-Tris-acetate and $1 \mathrm{~mm}$-EDTA, pH 8.0), and stained with ethidium bromide $(1 \mu \mathrm{g} / \mathrm{ml}$, final concentration). Images of the gels were recorded for further analysis in a gel documentation system (Vilber Lourmat).

\section{Acidifying activity of the isolates}

In order to determine acidifying activity, potantiometric $(\mathrm{pH}$ measurement) and titrimetric methods were used (Sagdıc et al. 2002; Xanthopoulous et al. 2001). Overnight cultures in MRS broths were inoculated into UHT skim milk at a $10 \mathrm{~g} / \mathrm{l}$ inoculum level. Lactic acid production and decrease in $\mathrm{pH}$ were recorded after the 3, 6, 9, and $24 \mathrm{~h}$ incubation. Both of the experiments were repeated twice. The amount of lactic acid was determined by titrating $2 \mathrm{ml}$ culture containing a few drops of the phenolphthalein indicator solution, against $0 \cdot 1 \mathrm{M}-\mathrm{NaOH}$ until the first traces of pink colour appeared. Each $\mathrm{ml} 0 \cdot 1 \mathrm{M}-\mathrm{NaOH}$ used for the titration was taken as equivalent to $9.008 \mathrm{mg}$ lactic acid (AOAC, 1980).

\section{Results}

\section{Phenotypic characterisation}

Initially, 661 isolates were obtained and tested for the coagulation of skim milk broths. Among these, 246 isolates displayed better coagulation properties. The remaining isolates, which could not coagulate skim milk or produced textural defects such as gas bubbles, were eliminated. Some of the selected isolates, which displayed heterogeneous cell morphology or poor growth profiles, were also eliminated. After these selection steps, 90 cocci and 17 bacilli remained, and these were subjected to further identification procedures. The cocci isolates were differentiated into two genera, Lactococcus and Enterococcus, on the basis of growth at $10{ }^{\circ} \mathrm{C}, 45^{\circ} \mathrm{C}$ and $65 \mathrm{~g} \mathrm{NaCl} / \mathrm{I}$ concentration. Arginine hydrolysis, citrate and sugar utilisation results indicated that all the lactococci isolates were Lc. lactis subsp. lactis (Teuber, 1995). Some of the LC. lactis subsp. lactis isolates (A26, A30, A47, A48, B10, B20, B21, B28, C4, C15, C16, C28, C32, and C35, Table 1) showed atypical properties such as growth at $45{ }^{\circ} \mathrm{C}$ and $65 \mathrm{~g} \mathrm{NaCl} / \mathrm{l}$ concentration. Thus it was somewhat difficult to differentiate these isolates from enterococci.

Enterococcal isolates consisted of 36 strains. On the basis of sugar fermentation profiles 26 of these isolates could be differentiated into 3 species (Garvie, 1984; Devriese \& Pot, 1995): 21 Ec. faecium, 3 Ec. faecalis, and 2 Ec. durans strains (Table 1). Arabinose, sorbitol and glycerol fermentation profiles enabled the discrimination of Ec. faecium strains from those of Ec. faecalis. Ec. durans strain was differentiated from the others because it could not ferment arabinose, mannitol, raffinose, sorbitol, trehalose, and xylose. Nevertheless, the remaining 10 enterococcal isolates could not be identified by the phenotypic methods (Table 1).

Twenty of the isolates were identified as lactobacilli since they were all Gram-positive, catalase-negative, and non-spore forming rod-shaped bacteria. Seventeen of the isolates could not produce $\mathrm{CO}_{2}$ from glucose thus they 
Table 1. Phenotypic and $16 \mathrm{~S}$ rRNA gene-ITS RFLP haplotype grouping of the isolates

RFLP

haplotype

HT1

HT2
HT3
HT4
H5
H6
H7
T5
T6
T7
T8
T9
Total

HT3

HT4

H6

$\mathrm{H} 7$

T5

T6

T8

Total
Strains

Lc. lactis ssp lactis (CECT 4432), A1, A2, A3, A5, A6, A7, A8, A9, A10, A11, A12, A13, A14, A16, A19, A20, A21,A22, A23, A25, A26, A27, A28, A29, A30, A40, A44, A45, A46, A47, A48, B8, B11, B15, B20, B21, C1, C10, C11, C15, C16, C18, C19l, C19ll, C22, C24, C32, C34, C35

A35, A37, C4, C34

C28

A17, A18, A60, A61, A62, A63, A64, A65

Ec. faecium (CECT 102), A31, A32, A33, A34, A38, A49, A50, B22, B23, B25, B26, B27, B28, B33, B34, C30, C31, C36 A41

A42, B24

A43, B16

A56, B17

Ec. faecalis (CECT 184), A39, A53, C38

C3, C5, C7, C8, C9, C12, C29, C37, D1, D3, D5, D6, D7, D8, D9

D2, D4
Phenotypic

identification

Lc. lactis subsp. lactis

Number

of

isolates

49

Lc. lactis subsp. lactis

Lc. lactis subsp. lactis

Enterococcus sp.

Ec. faecium

4

1

8

18

EC. faecium 1

Ec. faecium 2

Ec. durans 2

Enterococcus sp. $\quad 2$

Ec. faecalis 3

Lb. paracasei subsp. paracasei $\quad 15$

Lb. casei

HT haplotype strains: Haplotypes, identified with both of the restriction enzymes, HaellI (H) and Taql (T). H or T haplotype strains: Haplotypes, identified with only one of the restriction enzymes, Haelll $(\mathrm{H})$ or Taql $(\mathrm{T})$. Reference strains showing similar RFLP patterns with some of the isolated strains, were also included into respective haplotype groups

were considered to be homofermentative and selected. All of the lactobacilli isolates could grow at $15^{\circ} \mathrm{C}$. Thus they were of mesophilic type. Carbohydrate fermentation profiles enabled the identification of 15 of the isolates as Lb. paracasei subsp. paracasei (Hammes \& Vogel, 1995). Similarly 2 of the isolates, D2 and D4, were identified as Lb. casei.

\section{PCR-RFLP pattern analysis of $16 S$ rRNA gene-ITS region}

Amplification products of 16S rRNA gene-ITS DNA from 107 isolates and 5 reference strains were digested with Taql or HaellI. First, RFLP haplotypes specific to each of the restriction enzymes were identified by pooling the strains with identical restriction patterns, into different groups. Thus 16 RFLP groups, 7 Haell (H-groups) and 9 Taql (T-groups), were obtained. Four of these $\mathrm{H}$ - and T-groups contained identical strains. These groups were combined and re-named as HT-groups (HT1, HT2, HT3, and HT4, Table 1). Hence, in total 12 distinct RFLP haplotype groups were obtained from the restriction pattern analysis of 107 homofermentative strains (Table 1). One representative restriction pattern from each of these haplotype groups is shown in Fig. 1.

The HT haplotype groups included $58 \%$ of the isolates. Group HT1 contained the largest number of isolates $(45.4 \%)$, together with the reference strain Lc. lactis subsp. lactis (CECT 4432). Five of the Lc. lactis subsp. lactis isolates on the other hand formed two distinct haplotype groups, HT2 and HT3 (Table 1).

\section{Acidifying activity}

Thirty four of the $L c$. lactis subsp. lactis strains (A2, A3, A5, A6, A8, A9, A10, A11, A12, A13, A14, A20, A21, A22, A23, A25, A26, A27, A28, A30, A44, A45, A47, A48, B15, C1, C10, C11, C15, C18, C19l, C19lI, C22, and C24) which were included into the HT1 haplotype group (Table 1), were found to be capable of lowering the $\mathrm{pH}$ of UHT milk below $5 \cdot 3$ after $6 \mathrm{~h}$ incubation at $30{ }^{\circ} \mathrm{C}$ (area 1, Fig. 2). Only one of the Ec. faecium strains (A31 of $\mathrm{H} 5$, Table 1) had similar acidifying activity.

Acidifying profiles of the 34 Lc. lactis subsp. lactis strains $(62 \%)$ revealed that $\mathrm{pH}$ of UHT milk decreased sharply between 3 and $6 \mathrm{~h}$, and after $9 \mathrm{~h}$ incubation, it reached almost a stationary phase, at $\mathrm{pH} 4.4$ (area 1, Fig. 2). The profiles of remaining 20 lactococcal isolates were eliminated, because these profiles appeared to be overlapping with those of the enterococci and lactobacilli isolates, and making the diagram much more complicated. Enterococcal isolates did not seem to reach the same $\mathrm{pH}$ point even after $20 \mathrm{~h}$ incubation (area 2 and 2-3, representing acidifying profiles of $90 \%$ of the enterococcal isolates, Fig. 2). Lactobacilli strains displayed the slowest acidifying activity (area 2-3, and 3, representing 100\% of the lactobacilli isolates, Fig. 2).

Lactic acid production profiles of the isolated strains were also analysed (data not shown). For the Lc. lactis subsp. lactis strains lactic acid production started to increase immediately after the third hour of incubation, and reached plateau values between 6 and $8 \mathrm{mg}$ lactic acid/ml by the ninth $h$. The enterococcal strains, however, 


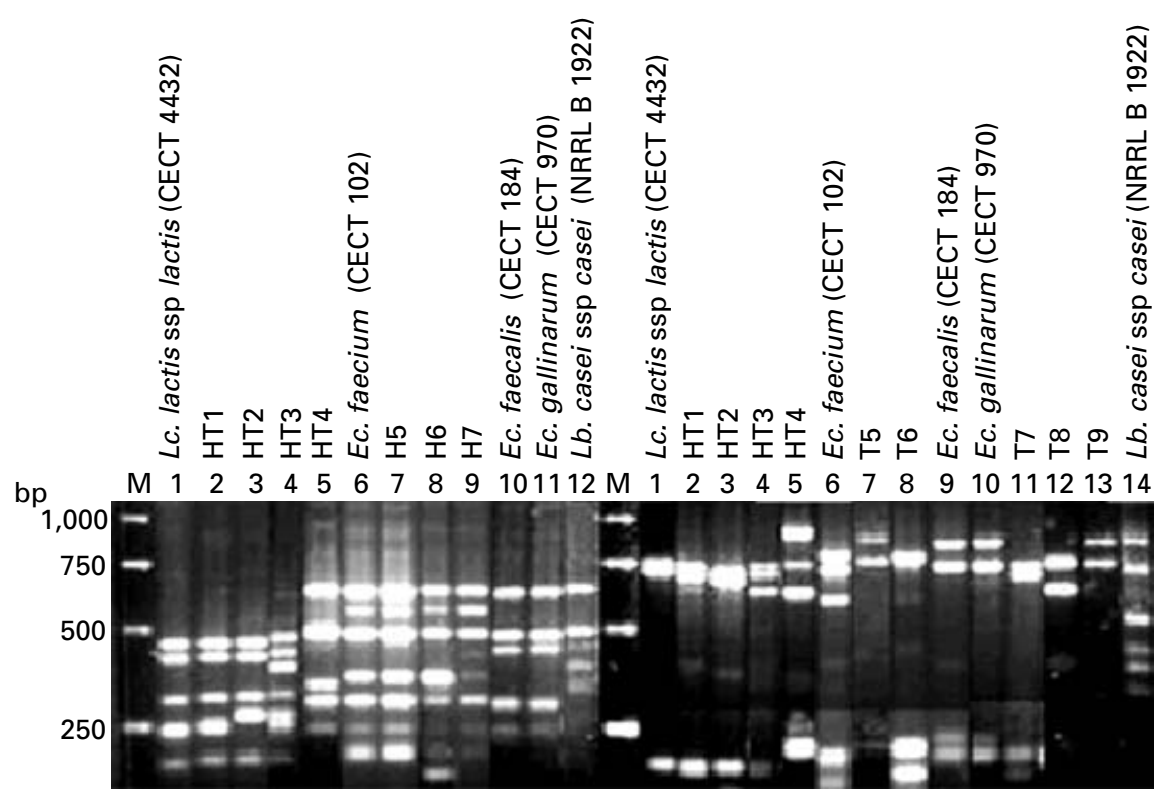

Fig. 1. PCR-RFLP profiles of the 12 haplotype groups. RFLP profiles of HT-haplotypes: Haell profiles (left), lanes 2, 3, 4, and 5; Taql profiles, lanes 2, 3, 4, and 5 (right). H-haplotypes, lanes 7, 8, and 9 (left). T-haplotypes, lanes 7, 8, 11, 12, and 13 (right). RFLP profiles of the five reference strains: with Haell, lanes 1, 6, 10, 11, and 12 (left); with Taql, lanes 1, 6, 9, 10, and 14 (right). Names of the RFLP haplotype groups and reference strains were indicated above the respective lanes. M was a DNA size marker (1 kb GeneRuler, MBI Fermentas).

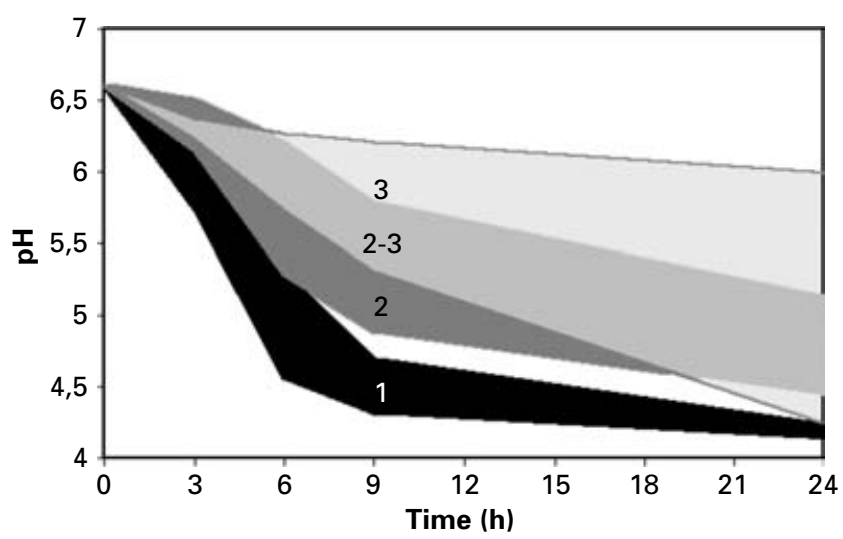

Fig. 2. Acidifying profiles of the isolated strains after $0,3,6,9$, and $24 \mathrm{~h}$ of incubation in UHT skim milk at $30^{\circ} \mathrm{C}$ : lactococcal profiles, area 1 (black); enterococcal profiles, areas 2 (dark grey) and 2-3; and profiles of lactobacilli, areas $2-3$ and 3 (light grey).

produced much less lactic acid, ranging from 4 to $6 \mathrm{mg} /$ $\mathrm{ml}$, at the same incubation period. For the lactobacilli isolates almost linear profiles were obtained until the end of $24 \mathrm{~h}$ incubation.

\section{Discussion}

Lc. lactis subsp. lactis is considered to be the most important Lactococcus species in cheese fermentation (López-Díaz et al. 2000). The abundance of Lc. lactis subsp. lactis in different types of cheese has been reported (Ayad et al. 2001; Delgado \& Mayo, 2003). A good acid producing starter $\mathrm{LAB}$ culture reduces the $\mathrm{pH}$ of milk from its normal value of 6.6 to 5.3 within $6 \mathrm{~h}$ incubation at $30{ }^{\circ} \mathrm{C}$ (Herreros et al. 2003). Technological characterisation results revealed unambiguously that 34 of the isolated lactococcal strains were able to lower the $\mathrm{pH}$ of UHT milk below 5.3 under such conditions. Twenty nine of these strains were isolated from a 4 day-old cheese sample, made of cows' milk, and 5 of them were from two, one day old, cheese samples, made of ewes' milk.

Fourteen of the lactococcal isolates showed atypical physiological properties, for example, growth in $65 \mathrm{~g}$ $\mathrm{NaCl} / \mathrm{l}$ and at $45{ }^{\circ} \mathrm{C}$. These features can be advantageous for the preparation of certain types of fermentation products. In a recent work, lactococcal isolates having similar atypical characteristics have also been reported (Fortina et al. 2003).

Identification of the lactococcal isolates was quite straightforward since there was a good correlation between the results of biochemical characterisation and of $16 S$ rRNA gene-ITS RFLP pattern analysis. Both HaellI and Taql digestion profiles could easily differentiate these isolates (HT1, Table 1) except 5 strains which displayed diverged RFLP patterns (strains of HT2 and HT3, Table 1).

Enterococci, have been known to be slow acid producers (Sarantinopoulos et al. 2001). In agreement with the literature, only one enterococcal isolate, A31 $(\mathrm{H} 1$, Table 1), was found to lower the $\mathrm{pH}$ below 5.5 after $6 \mathrm{~h}$ incubation. 
The presence of enterococci in cheese has been questioned because they are known as the cause of some serious health problems, such as endocarditis and urinary tract infection (Beresford et al. 2001). Numbers of enterecocci in Mediterranean type of cheese for example can be as high as $10^{6} \mathrm{cfu} / \mathrm{g}$, in curds, and $10^{7} \mathrm{cfu} / \mathrm{g}$ in the fully ripened cheese (Franz et al. 2003). They have on the other hand beneficial effects on the flavour development in many types of cheese (Lopéz-diaz et al. 2000). Eight of the enterococcal isolates (A39, A43, A53, A56, A60, B33, C30, C38; Table 1), for example, could produce gas from citrate. The breakdown of citrate results in the production of carbon dioxide and also some flavour compounds such as diacetyl, acetaldehyde, and acetoin. Besides bacteriocin production ability of enterococci is also beneficial in controlling the growth of some food pathogens (Sarantinopoulos et al. 2001). Thus, for such characteristics and together with other desirable technological and metabolic properties, enterococci have also been suggested as part of the defined starter cultures for different European cheeses (Franz et al. 2003).

Some of the enterococcal isolates could not be identified by the phenotypical characterisation methods. Similar problems have also been reported by others (Devriese \& Pot, 1995; Andrighetto et al. 2001). On the other hand, 16S rRNA gene-ITS RFLP pattern analysis, especially with Haelll restriction enzyme, was found to be useful for the identification of most of the enterococcal isolates.

Lactobacilli are mostly involved in the ripening period of cheese manufacturing and they are rarely used as starters (Stiles \& Holzapfel, 1997). In agreement with these reports, none of the lactobacilli isolates seemed to reduce the $\mathrm{pH}$ below $5 \cdot 7$ in $6 \mathrm{~h}$.

Phenotypic characterisation results suggested that 15 of the lactobacilli isolates could be identified as $L b$. paracesei subsp. paracasei, and two isolate, D2 and D4, as Lb. casei (Table 1). In accordance with these results, 16S rRNA gene-ITS RFLP profiles also divided these isolates into two RFLP haplotype groups, T4 and T5 (Table 1). However, a comparative identification of the lactobacilli isolates, using relevant reference strains, is still required.

\section{References}

Andrighetto C, Knijff E, Lombardi A, Torriani S, Vancanneyt M, Kersters K, Swings J \& Dellaglio F 2001 Phenotypic and genetic diversity of enterococci isolated from Italian cheeses. Journal of Dairy Research $\mathbf{6 8}$ 303-316

AOAC 1980 Official Methods of Analysis, 13th Edn. Washington DC, association of Official Analytical Chemist

Ayad EHE, Verheul A, Wouters JTM \& Smit G 2001 Population dynamics of lactococci from industrial, artisanal and non-dairy origins in defined strain starter for Gouda-type cheese. International Dairy Journal 11 $51-61$

Beresford TP, Fitzsimons NA, Brennan NL \& Cogan TM 2001 Recent advances in cheese microbiology. International Dairy Journal $\mathbf{1 1}$ 259-274
Cardinal MJ, Meghrous J, Lacroix C \& Simard RE 1997 Isolation of Lactococcus lactis strain producing inhibitory activity against Listeria. Food Biotechnology 11 129-146

Cogan TM, Barbosa M, Beuvier E, Bianchi-Salvadori B, Cocconcelli PS, Fernandes I, Gomez J, Gomez R, Kalantzopoulos LA, Medina M, Rea MC \& Rodriguez E 1997 Characterisation of the lactic acid bacteria in artisanal dairy products. Journal of Dairy Research 64 409-421

Delgado S \& Mayo B 2003 Phenotypic and genetic diversity of Lactococcus lactis and Enterococcus spp. strains isolated from Northern Spain starter-free farmhouse cheeses. International Journal of Food Microbiology 90 309-319

De Man JC, Rogosa M \& Sharpe ME 1960 Medium for the cultivation of lactobacilli. Journal of Applied Bacteriology 23 193-198

De Urraza PJ, Gomez-Zavaglia A, Lozano EM, Romanowski V \& De Antoni GL 2000 DNA fingerprinting of thermophilic lactic acid bacteria using repetitive sequence-based polymerase chain reaction. Journal of Dairy Research 67 381-392

Devriese LA \& Pot B 1995 The genus Enterecoccus. In The Genera of Lactic acid Bacteria, pp. 327-361 (Eds BJB Wood \& WH Holzapfel). Glasgow: Blackie Academic and Professional

Fortina MG, Ricci G, Acquati A, Zeppa G, Gandini A \& Manachini PL 2003 Genetic characterisation of some lactic acid bacteria occurring in an artisanal protected denomination origin (PDO) Italian cheese, the Toma piemontese. Food Microbiology 20 397-404

Franz C, Stiles M, Schleifer H \& Holzapfel W 2003 Enterococci in foods a conundrum for food safety. International Journal of Food Microbiology 88 105-122

Garvie EI 1984 Taxonomy and identification of bacteria important in cheese and fermented dairy products. In Advances in the Microbiology and Biochemistry of Cheese and Fermented Milk, pp. 35-66 (Eds FL Davies \& BA Law). London: Elsevier applied science publishers

Hammes WP \& Vogel RF 1995 The genus Lactobacillus. In The Genera of Lactic acid Bacteria, pp. 19-49 (Eds BJB Wood \& WH Holzapfel). Glasgow: Blackie Academic and Professional

Herreros MA, Fresno JM, Prieto G \& Tornadijo ME 2003 Technological characterisation of lactic acid bacteria isolated from Armada cheese (a Spanish goat's milk cheese). International Dairy Journal 13 469-479

Jensen MA, Webster JA \& Strauss N 1993 Rapid identification of bacteria on the basis of polymerase chain reaction-amplified ribosomal DNA spacer polymorphisms. Applied and Environmental Microbiology 59 943-952

Lopez-Diaz TM, Alonso C, Roman C, Garcia-Lopez ML \& Moreno B 2000 Lactic acid bacteria isolated from a hand-made blue cheese. Food Microbiology 17 23-32

Mora B, Fortina MG, Nicastro G, Parini C \& Manachini PL 1998 Genotypic characterisation of thermophilic bacilli: a study on new soil isolates and several reference strains. Research in Microbiology 149 711-722

Sagdic O, Arici M \& Simsek O 2002 Selection of starters for a traditional Turkish Yayik butter. Food Microbiology 19 303-312

Sambrook J, Fritsch EF \& Maniatis T 1989 Molecular Cloning: A Laboratory Manual, 2nd Edn. Cold Spring Harbour, NY: Cold Spring Harbour Laboratory Press

Sarantinopoulos P, Andrightetto C, Georgalaki MD, Rea MC, Lombardi A, Coga TM, Kalantzopoulos G \& Tsakalidou E 2001 Biochemical properties of enterococci relevant to their technological performance. International Dairy Journal 11 621-647

Stiles ME \& Holzapfel WH 1997 Lactic acid bacteria of foods and their current taxonomy. International Journal of Food Microbiology 36 1-29

Terzaghi BE \& Sandine VE 1975 Improved medium for lactic streptococci and their bacteriophages. Applied Microbiology 29 807-813

Teuber M 1995 The genus Lactococcus. In The Genera of Lactic acid Bacteria, pp. 173-230 (Eds BJB Wood \& WH Holzapfel). Glasgow: Blackie Academic and Professional

Xanthopoulos V, Petridis D \& Tzanetakis N 2001 Characterisation and classification of Streptococcus thermophilus and Lactobacillus delbrueckii subsp. bulgaricus strains isolated from traditional Greek yogurts. Food Microbiology and Safety 66 747-752 